\title{
Productivity of Laying Alabio Duck and its Eggs Quality under Exposure of Different Intensity and Color of LED Light
}

\author{
T. Rostini ${ }^{\mathrm{a}, *}$, D. Biyatmoko ${ }^{\mathrm{b}}$, \& A. Wahdi ${ }^{\mathrm{b}}$ \\ ${ }^{a}$ Department of Animal Science, Faculty of Agriculture, Universitas Islam Kalimantan \\ Jalan Adyaksa No.2 Kayutangi Banjarmasin South Kalimantan, Indonesia \\ ${ }^{b}$ Department of Animal Science, Faculty of Agriculture, Universitas Lambung Mangkurat \\ Jalan A. Yani Km 36 Banjarbaru, South Kalimantan, Indonesia \\ ${ }^{*}$ Corresponding author: tintin_rostini@yahoo.com \\ (Received 09-09-2020; Revised 21-02-2020; Accepted 05-03-2021)
}

\begin{abstract}
The purpose of this study was to analyze the different combinations of intensity and color of LED monochrome lamps for optimal productivity, as well as the internal and external quality of Alabio duck eggs. The study was carried out for 4 weeks period of raising which was devided in 2 stages. In the first stage, it was used a completely randomized factorial design of 4 light colors $x 3$ light intensities with 4 replications with 5 ducks of each replicate, totaling 240 laying Alabio ducks. The light color was 4 colors consisted of yellow, red, blue, and green, alongside with intensity levels of 10 lux, 15 lux, and 20 lux. The irradiation method of layer ducks was 18 hours light and 10 hours dark (18L: 10D of ahemeral method). The variables observed were laying age, egg production and the total weight of eggs, mortality, feed consumption, FCR, and income over feed cost (IOFC). In the second stage, it was selected 3 best combination treatments from the first phase. The experimental method was based on a completely randomized design, encompassing the best treatments as P1, P2, and P3, with 5 replications with 10 duck per replicate, totaling 150 laying Alabio ducks. The variables were egg internal quality, which consisted of haugh unit egg, yolk index (EYI), egg albumin index, and yolk color. The external egg quality observed were egg weight, shell thickness, shape index, and specific gravity. The results of the first phase showed the best productivity was achieved in blue color with an intensity of 15 lux on all measured variables. The results in the second stage showed the best treatment is blue light color treatment with a light intensity of 15 lux, on the internal qualities of duck eggs include HU (95.11 \pm 2.39$)$, EYI $(0.421 \pm 0.63)$, EAI $(0.121 \pm 0.12)$, egg yolk color $(8.36 \pm 0.31)$, and also the best in terms of external quality, with the highest egg weight $(66.76 \pm 5.21 \mathrm{~g})$. It was concluded that the combination of blue light color with an intensity of 15 lux significantly increased the egg production and performance of Alabio duck from Kalimantan.
\end{abstract}

Keywords: color and intensity; ahemeral; monochromatic light; duck productivity; egg quality

\section{INTRODUCTION}

Alabio duck is one of the poultry genetic resources in Indonesia. It contributes $54.5 \%$ of the communitys' total egg demands, and higher than the contribution of laying hens. The Alabio duck egg has been commercialized intensively in South Kalimantan. The area has light periodicity ranging from 10-11 hours/day, fulfilling the light needs for Alabio ducks to grow: well up to the pullet period. However, when entering the laying period ( $>6$ months of age), it requires an additional 3-4 hours of light at night, to support the proper ovulation process (Biyatmoko, 2016).

Adequate light intensity is required for the release of reproductive hormones (FSH and $\mathrm{LH}$ ), and also the synthesis and secretion of estradiol. These hormones are needed to guarantee the number of functional (mature) ovarian follicles and sustainable eggs produced (Liu et al., 2015), with a supportive intensity range of 10-20 lux (Shabiha et al., 2013; Svobodová et al., 2015). Meanwhile, color is defined as the wavelength of light that stimulates the retina and consequently result in poultry behavior changes, in terms of activity, aggressiveness, and eating behavior (Svobodová et al., 2015). Olanrewaju et al. (2012) reported on the need to maintain a certain wavelength, to increase egg production of broiler, due to the significant relationship.

Monochromatic light with light-emitting diode (LED) lamps has been used as the main light source in most modern poultry farms, due to the numerous benefits. These include the efficiency of electrical energy, color emission stability, brightness, durability (long life), and the ability to reduce cage humidity. Moreover, another significant role is a positive response in the aspect of reproduction and production (Kasiyati, 2018). Elert (2008) stipulated the insignificant distance between 
wavelengths of a single frequency, as an important advantage of the LED. The electromagnetic spectrum of monochromatic light (LED) has a single color, and this is based on the wavelength, as seen in red $(630-760 \mathrm{~nm})$, orange (590-630 nm), yellow (570-590 nm), green (500$570 \mathrm{~nm})$, blue $(450-500 \mathrm{~nm})$, and purple $(400-450 \mathrm{~nm})$.

The ahemeral method is used to add LED light by increasing the length of the day to 28 hours, encompassing 18 and 10 hours of light and dark, respectively (18L; 10D). This technique increases egg production, and also improves the egg's internal and external quality. In addition, the parameters for egg internal quality include haugh unit (HU), egg yolk index (EYI), egg albumin index (EAI), and yolk color, while the external quality includes weight, egg shape index (ESI), shell thickness, and specific gravity. Kasiyati et al. (2016) reported on the ability of LEDs with blue light and intensity of 15-25 lux to increase serum estradiol concentration in laying quails, followed by an upsurge in ovarian weight and F1 follicle diameter. This phenomenon results in the greater yolk (vittelin) and the augmentation of egg weights. In addition, colors with less light intensity are known to inhibit ovulation stimulation, which often results from disrupting the release of gonadotropin hormone. The blue and green lights stimulate the ducks still in calmness condition, and also positively influence the efficiency of feed utilization and conversion into egg production (Hassan, et al., 2013). Meanwhile, yellow and red lights tend to increase aggression and activity, improve feed consumption, and are widely used to elevate the energy level for locomotion, alongside a decline in egg production. However, the energy efficiency is fully manifested in higher productivity, and ducks when they were exposed to blue and green LED monochromatic lights generate larger and heavier eggs (Freitas et al., 2010).

North \& Bell (1992) affiliated the increase in egg weight to an elevation in yolk weight (vittelin) released in the infundibulum of the poultry reproductive tract, constituting $22 \%-25 \%$ of the total value. Gordon (1994) reported on some reasons for adding light to poultry, and this included increasing the period and chance to eat, drink, and perform other activities, thus augmenting feed consumption. This phenomenon correlates with increased protein, alongside the yolk (vittelin) formed, and consequently the egg weight. Chew et al. (2016) reported on the ability of monochromatic blue LEDs to augment the Haugh Unit (HU) by 62.64, and the yolk index by 0.6314 . These values are higher than the effects of the green and red colors in quail. The result is in line with Borille et al. (2015), where blue light with a short wavelength of $450 \mathrm{~nm}$ directly penetrated and was absorbed by the skull bones and cranial tissue, to be further received by the extraretinale photoreceptors, and passed on to the hypothalamus. There may be various things related to the stimulation of light in response to growth. Studies on the physiological aspects of the lighting of poultry have been widely investigated, however research in combination with LED lighting is very limited based on that background. The purpose of this study was to determine the effect of giving a combination of mono- chromatic LED light with different ahemeral methods on egg production and internal and external qualities of Alabio laying duck eggs.

\section{MATERIALS AND METHODS}

Seven-month old Alabio duck at the egg production phase were used. The study was carried out in poultry cages for 16 weeks, divided into two stages of 8 weeks each including 4 weeks for variables observation. This study was carried out with the approval of the animal ethics committee with approval number $P$. 010.05.20. from the Research and Community Service of Islamic University of Kalimantan.

\section{Research Methods}

Stage I. The first stage of experiment was conducted for 8 weeks and 4 weeks were used for measurements of parameters. The research method used was a completely randomized design, with a $4 \times 3$ factorial pattern and 4 replications, totaling 240 Alabio laying ducks. The first factor was light color consisting of 4 levels, i.e., C1 (yellow), C2 (red), C3 (blue), C4 (green), along with 3 levels of light intensity factor consisting of N1 (10 lux), N2 (15 lux), and N3 (20 lux), cumulating to 12 treatment combinations. The light intensity was measured using a lux meter (Kim et al., 2014). The length of the day was increased to 28 hours each, at 18 and 10 hours, respectively, for light and dark (18L: 10D), using the ahemeral method. A black curtain was used to regulate the opening and closing of additional bright hours in the cage.

The dietary feed contained $18 \%$ crude protein, $2800 \mathrm{kcal}$ metabolizable energy $/ \mathrm{kg}, 2.5 \% \mathrm{Ca}$, and $1.5 \%$ P. Variables observed included the age at first egg, egg production (weight and DDP), total egg weight, mortality, feed consumption, feed conversion ratio (FCR), and income over feed cost (IOFC).

Stage II. In this second stage, the ducks were kept for another 8 weeks, including 4 weeks of variable observation. The experimental treatment in the second stage was based on the three best-recommended treatments resulted in Stage I, by attributing the new treatment code of P1 (best 1), P2 (best 2), and P3 (best 3). The investigation was then aimed to identify the best effect of monochromatic LED, on the internal and external quality of the egg, which was evaluated according to Liu et al. (2014). The completely randomized design, with 3 treatments (P1; P2; P3) and 5 replications containing 5 laying ducks each, hence a total of 75 were examined. The black curtain was also used to regulate the opening and closing of the additional bright hours, while the dietary ration was iso protein and iso energy, containing $18 \%$ crude protein, $2800 \mathrm{kcal}$ Metabolizable Energy (ME)/kg, 6\% fiber, $2.5 \%$ Calcium, and 1.5\% Phosphorus. Drinking water was provided ad libitum, and the variables observed were (1) internal egg quality variable, consisting of haugh unit (HU), egg yolk index, egg albumin index, yolk color and (2) external egg quality variable consisted of egg weight, shell thickness, shape index, and specific gravity. 


\section{Data Analysis}

The data were analyzed using analysis of variance (ANOVA), followed by mean difference test, using the Duncan Multiple Range Test (DMRT) at the 5\% and 1\% significance levels (Mattjik \& Sumertajaya, 2006).

\section{RESULTS}

Egg productivity is a measure of success in this study, being a factor for determining the importance of elevated irradiation length of LED monochromatic light, using the ahemeral method (18L: 10D) on laying ducks. In addition, productivity is divided into three main variables, including production level (henday), total and average egg production. Based on the analysis of variance, these parameters were significantly affected by the color and intensity combination at $(p<0.05)$ (Table 1). The C3N2 treatment (a combination of blue light color with an intensity of 15 lux) provided the highest total production of $336 \pm 4.5 \mathrm{egg} / \mathrm{duck} / 4$ weeks, as well as the most significant average production $(22.40 \pm 4.5 \mathrm{eggs} /$ ducks), and the highest production level $(80.57 \pm 1.3 \%$ duck day (DDP)). Conversely, C1N2 treatment (the interaction of yellow light color with an intensity of 15 lux) demonstrated the lowest values of $196 \pm 5.7 \mathrm{egg} /$ duck/4 weeks, $13.06 \pm 5.7$ egg/duck, and $46.67 \pm 1.3 \%$ duck day (DDP), respectively.

\section{Performance of Alabio Duck Production}

Table 2 shows the performance of Alabio duck production through color exposure and light intensity of LED monochromatic lamps. Based on the first egglaying age, the results showed a significant influence of color exposure and monochromatic LED light intensity $(\mathrm{p}<0.05)$. This was early for C3N2 treatment (interaction of blue light color with an intensity of 15 lux) at $164 \pm 1.9$

Table 1. Egg production of Alabio duck under expouse to different light colors and intensities of LED monochromatic lamps for four weeks period

\begin{tabular}{|c|c|c|c|}
\hline \multirow{2}{*}{ Treatments } & \multicolumn{3}{|c|}{ Egg production } \\
\hline & Total (egg/4 weeks) & Average (egg/duck) & Production level (\%, DDP) \\
\hline C1N1 & $196.08 \pm 2.6^{\mathrm{a}}$ & $13.06 \pm 4.6^{\mathrm{a}}$ & $47.57 \pm 1.3^{\mathrm{a}}$ \\
\hline C1N2 & $196.24 \pm 4.5^{\mathrm{a}}$ & $13.06 \pm 5.7^{\mathrm{a}}$ & $46.67 \pm 1.3^{\mathrm{a}}$ \\
\hline C1N3 & $224.41 \pm 2.2^{\mathrm{b}}$ & $14.93 \pm 4.3^{\mathrm{b}}$ & $54.10 \pm 1.3^{\mathrm{b}}$ \\
\hline C2N1 & $252.16 \pm 3.4^{b}$ & $16.80 \pm 6.1^{b}$ & $61.91 \pm 1.6^{\mathrm{b}}$ \\
\hline $\mathrm{C} 2 \mathrm{~N} 2$ & $252.22 \pm 4.6^{\mathrm{b}}$ & $16.80 \pm 5.4^{b}$ & $60.00 \pm 1.1^{\mathrm{b}}$ \\
\hline $\mathrm{C} 2 \mathrm{~N} 3$ & $280.28 \pm 3.1^{\mathrm{c}}$ & $18.66 \pm 4.6^{c}$ & $69.47 \pm 1.2^{\mathrm{c}}$ \\
\hline C3N1 & $280.42 \pm 3.4^{c}$ & $18.66 \pm 4.2^{\mathrm{c}}$ & $66.67 \pm 1.1^{\mathrm{c}}$ \\
\hline $\mathrm{C} 3 \mathrm{~N} 2$ & $336.52 \pm 2.7 \mathrm{e}$ & $22.40 \pm 4.5^{\mathrm{e}}$ & $80.57 \pm 1.3^{\mathrm{e}}$ \\
\hline $\mathrm{C} 3 \mathrm{~N} 3$ & $308.12 \pm 1.8^{\mathrm{d}}$ & $20.53 \pm 3.9^{d}$ & $73.33 \pm 1.1^{\mathrm{d}}$ \\
\hline C4N1 & $280.04 \pm 3.4^{\mathrm{c}}$ & $18.66 \pm 4.9^{c}$ & $66.67 \pm 1.1^{\mathrm{c}}$ \\
\hline C4N2 & $308.14 \pm 4.6^{\mathrm{d}}$ & $20.53 \pm 5.5^{\mathrm{d}}$ & $73.33 \pm 1.1^{\mathrm{d}}$ \\
\hline C4N3 & $308.56 \pm 3.2^{\mathrm{d}}$ & $20.53 \pm 6.1^{\mathrm{d}}$ & $73.33 \pm 1.1^{\mathrm{d}}$ \\
\hline
\end{tabular}

Note: DDP= duck day production; C= Light color, C1 (yellow), C2 (red), C3 (Blue), C4 (Green); N= Light intensity, N1 (10 lux) , N2 (15 lux), N3 ( 20 lux) Means in the same column with different superscripts differ significantly $(\mathrm{p}<0.05)$.

Table 2. Performance of laying Alabio duck under exposure to different light colors and intensities of LED monochromatic lamps for four weeks period

\begin{tabular}{cccccc}
\hline Treatments & $\begin{array}{c}\text { Age at the first egg } \\
\text { laid (day) }\end{array}$ & $\begin{array}{c}\text { Total egg weight } \\
\text { (g/duck) }\end{array}$ & $\begin{array}{c}\text { Feed consumption } \\
\text { (g/duck) }\end{array}$ & $\begin{array}{c}\text { Feed conversion } \\
\text { ration }\end{array}$ & $\begin{array}{c}\text { Duck mortality } \\
(\%)\end{array}$ \\
\hline C1N1 & $172.13 \pm 2.1^{\mathrm{b}}$ & $800.98 \pm 11.6^{\mathrm{a}}$ & $736.88 \pm 10.6^{\mathrm{a}}$ & $6.44 \pm 1.1^{\mathrm{a}}$ & $6.67 \pm 1.1$ \\
C1N2 & $179.22 \pm 2.7^{\mathrm{c}}$ & $800.98 \pm 13.7^{\mathrm{a}}$ & $727.72 \pm 9.7^{\mathrm{a}}$ & $6.36 \pm 1.3^{\mathrm{a}}$ & $0.00 \pm 0.0$ \\
C1N3 & $183.56 \pm 1.9^{\mathrm{c}}$ & $915.41 \pm 14.3^{\mathrm{b}}$ & $802.92 \pm 14.3^{\mathrm{b}}$ & $6.14 \pm 1.1^{\mathrm{b}}$ & $6.67 \pm 1.1$ \\
C2N1 & $167.64 \pm 3.3^{\mathrm{a}}$ & $1029.84 \pm 16.1^{\mathrm{b}}$ & $863.56 \pm 12.1^{\mathrm{b}}$ & $5.87 \pm 1.5^{\mathrm{b}}$ & $6.67 \pm 1.1$ \\
C2N2 & $172.18 \pm 2.3^{\mathrm{b}}$ & $1029.84 \pm 15.4^{\mathrm{b}}$ & $857.68 \pm 12.4^{\mathrm{b}}$ & $5.83 \pm 2.2^{\mathrm{b}}$ & $0.00 \pm 0.0$ \\
C2N3 & $174.09 \pm 2.6^{\mathrm{b}}$ & $1144.26 \pm 17.6^{\mathrm{c}}$ & $871.24 \pm 15.6^{\mathrm{c}}$ & $5.33 \pm 1.7^{\mathrm{c}}$ & $6.67 \pm 1.1$ \\
C3N1 & $168.13 \pm 2.2^{\mathrm{a}}$ & $1144.26 \pm 15.2^{\mathrm{c}}$ & $874.52 \pm 12.2^{\mathrm{c}}$ & $5.35 \pm 1.6^{\mathrm{c}}$ & $0.00 \pm 0.0$ \\
C3N2 & $164.36 \pm 1.9^{\mathrm{a}}$ & $1373.12 \pm 16.5^{\mathrm{e}}$ & $810.12 \pm 13.5^{\mathrm{e}}$ & $4.13 \pm 1.3^{\mathrm{e}}$ & $6.67 \pm 1.1$ \\
C3N3 & $168.28 \pm 2.4^{\mathrm{a}}$ & $1258.69 \pm 12.9^{\mathrm{d}}$ & $830.72 \pm 11.9^{\mathrm{d}}$ & $4.62 \pm 1.2^{\mathrm{d}}$ & $0.00 \pm 0.0$ \\
C4N1 & $168.14 \pm 2.3^{\mathrm{a}}$ & $1144.26 \pm 14.9^{\mathrm{c}}$ & $885.96 \pm 12.9^{\mathrm{c}}$ & $5.42 \pm 1.6^{\mathrm{c}}$ & $0.00 \pm 0.0$ \\
C4N2 & $169.07 \pm 2.3^{\mathrm{ab}}$ & $1258.69 \pm 13.5^{\mathrm{d}}$ & $819.92 \pm 12.5^{\mathrm{d}}$ & $4.56 \pm 1.9^{\mathrm{d}}$ & $0.00 \pm 0.0$ \\
C4N3 & $171.32 \pm 1.5^{\mathrm{ab}}$ & $1258.69 \pm 14.1^{\mathrm{d}}$ & $827.12 \pm 14.1^{\mathrm{d}}$ & $4.60 \pm 1.9^{\mathrm{d}}$ & $0.00 \pm 0.0$ \\
\hline
\end{tabular}

Note: DDP= duck day production; C= Light color, C1 (yellow), C2 (red), C3 (Blue), C4 (Green); N= Light intensity, N1 (10 lux) , N2 (15 lux), N3 ( 20 lux) Means in the same column with different superscripts differ significantly $(p<0.05)$. 
days, followed by C2N1 (red light color with an intensity of $10 \mathrm{lux}$ ) at $167 \pm 3.3$ days, and C3N3 (blue light color with an intensity of 20 lux) at $168 \pm 2.4$ days, while the longest at $183 \pm 1.9$ days was reported in C1N3 (yellow light color with an intensity of 20 lux).

\section{Income Over Feed Cost (IOFC)}

Income over feed cost (IOFC) is the business revenue obtained from animal husbandry activities, evaluated by examining the difference margin between the value of egg sales output and the ration costs. Furthermore, higher values are the indication of more significant business revenues or generated profits. Table 3 demonstrated the highest income or IOFC, as observed in C3N2 treatment (a combination of blue light colors with an intensity of 15 lux), at IDR 29,405.39 \pm 333.1 per duck, with egg selling value of IDR $54,924.80 \pm 446.5$ per head, and feed consumption cost of IDR $25,519.41 \pm 289.5$ per duck. However, C1N1 (a combination of yellow light with an intensity of $10 \mathrm{lux}$ ) had the lowest revenue at IDR $8,826.81 \pm 121.1$ per duck, IDR $32,039.20 \pm 311.6$ per head, and IDR 23,212.40 \pm 250.6 per duck, respectively. The values obtained were very linear with the egg production and feed use efficiency (FCR).

\section{Performance of Internal and External Quality of Eggs}

Table 4 shows the effect of varied LED monochromatic lamp color and intensity on the internal and external quality parameters of Alabio duck eggs. The color and light intensity interaction has a significant effect $(p<0.05)$ on the age at first laying eggs, where C3N2 treatment, namely the interaction of blue light color with light intensity 15 lux). This significant effects were observed on the variables of haugh unit (HU), egg yolk index (EYI), egg albumin index (EAI), and yolk color $(\mathrm{p}<0.05)$. Table 4 highlights P1 (interaction of blue

Table 3. Income Over Feed Cost (IOFC) of laying Alabio Ducks under exposure to different light colors and intensities of LED monochromatic lamp for four weeks period

\begin{tabular}{cccc}
\hline Treatments & $\begin{array}{c}\text { Sealling value of eggs } \\
\text { (IDR/duck) }\end{array}$ & $\begin{array}{c}\text { Cost of feed consumption } \\
\text { (IDR/duck) }\end{array}$ & IOFC \\
\hline C1N1 & $32,039.20 \pm 311.6^{\mathrm{a}}$ & $23,212.40 \pm 250.6^{\mathrm{a}}$ & $8,826.81 \pm 121.1^{\mathrm{a}}$ \\
C1N2 & $32,039.20 \pm 312.7^{\mathrm{a}}$ & $22,924.03 \pm 259.7^{\mathrm{a}}$ & $9,115.17 \pm 115.3^{\mathrm{a}}$ \\
C1N3 & $36,616.40 \pm 334.3^{\mathrm{b}}$ & $25,292.74 \pm 224.3^{\mathrm{b}}$ & $11,323.66 \pm 161.1^{\mathrm{b}}$ \\
C2N1 & $41,193.60 \pm 476.1^{\mathrm{b}}$ & $27,203.20 \pm 202.1^{\mathrm{b}}$ & $13,990.38 \pm 189.5^{\mathrm{b}}$ \\
C2N2 & $41,193.60 \pm 415.4^{\mathrm{b}}$ & $27,017.82 \pm 212.4^{\mathrm{b}}$ & $14,175.78 \pm 170.2^{\mathrm{b}}$ \\
C2N3 & $45,770.40 \pm 427.6^{\mathrm{c}}$ & $27,445.05 \pm 205.6^{\mathrm{c}}$ & $18,325.35 \pm 211.7^{\mathrm{c}}$ \\
C3N1 & $45,770.40 \pm 435.2^{\mathrm{c}}$ & $27,548.10 \pm 312.2^{\mathrm{c}}$ & $18,222.35 \pm 191.6^{\mathrm{c}}$ \\
C3N2 & $54,924.80 \pm 446.5^{\mathrm{e}}$ & $25,519.41 \pm 289.5^{\mathrm{e}}$ & $29,405.39 \pm 333.1^{\mathrm{e}}$ \\
C3N3 & $50,347.60 \pm 452.9^{\mathrm{d}}$ & $26,168.13 \pm 261.9^{\mathrm{d}}$ & $24,179.47 \pm 211.2^{\mathrm{d}}$ \\
C4N1 & $45,770.40 \pm 313.9^{\mathrm{c}}$ & $27,908.50 \pm 212.9^{\mathrm{c}}$ & $17,861.94 \pm 221.6^{\mathrm{c}}$ \\
C4N2 & $50,347.60 \pm 454.5^{\mathrm{d}}$ & $25,828.29 \pm 212.5^{\mathrm{d}}$ & $24,519.31 \pm 211.9^{\mathrm{d}}$ \\
\hline
\end{tabular}

Note: DDP= duck day production; C= Light color, C1 (yellow), C2 (red), C3 (Blue), C4 (Green); N= Light intensity, N1 (10 lux) , N2 (15 lux), N3 ( 20 lux) Means in the same column with different superscripts differ significantly $(\mathrm{p}<0.05)$.

IOFC= Income Over Feed Cost; feed price of IDR 4500/kg; the price of duck egg IDR 2500/egg; $1 \mathrm{~kg}$ of eggs is equivalent to 16 eggs of Alabio duck; one egg averaging $61.3 \mathrm{~g}$.

Table 4. Internal and external quality performance of laying Alabio Ducks under exposure to different light colors and intensities of LED monochromatic lamp for four weeks period

\begin{tabular}{lrrr}
\hline \multicolumn{1}{c}{ Variables } & \multicolumn{1}{c}{ Treatments } \\
\cline { 2 - 4 } & \multicolumn{1}{c}{ P1 } & \multicolumn{1}{c}{ P2 } \\
\hline Internal quality: & & & $91.650 \pm 4.88^{\mathrm{a}}$ \\
Haugh Unit (HU) & $95.110 \pm 2.39^{\mathrm{b}}$ & $93.540 \pm 5.11^{\mathrm{b}}$ & $0.392 \pm 0.66^{\mathrm{a}}$ \\
Egg Yolk Index (EYI) & $0.421 \pm 0.63^{\mathrm{c}}$ & $0.408 \pm 0.45^{\mathrm{b}}$ & $0.103 \pm 0.19^{\mathrm{a}}$ \\
Egg Albumin Index (EAI) & $0.133 \pm 0.12^{\mathrm{c}}$ & $0.121 \pm 0.16^{\mathrm{b}}$ & $7.120 \pm 0.33^{\mathrm{a}}$ \\
Egg Yolk Color & $8.360 \pm 0.31^{\mathrm{b}}$ & & $6.860 \pm 0.26^{\mathrm{ab}}$ \\
External quality : & & & $0.3088 \pm 0.07^{\mathrm{a}}$ \\
Egg weight (g/egg) & $66.7635 \pm 5.21^{\mathrm{b}}$ & $0.3215 \pm 0.07^{\mathrm{b}}$ & $71.5290 \pm 5.22^{\mathrm{a}}$ \\
Eggshell thickness (mm) & $0.3367 \pm 0.05^{\mathrm{c}}$ & $73.0319 \pm 4.55^{\mathrm{b}}$ & $1.1430 \pm 0.11^{\mathrm{a}}$ \\
Egg Shape Index (ESI) & $74.0393 \pm 2.15^{\mathrm{b}}$ & $1.0412 \pm 0.09^{\mathrm{b}}$ & \\
Egg specific gravity (g.m $\left.{ }^{3}\right)$ & $1.0522 \pm 0.12^{\mathrm{b}}$ &
\end{tabular}

Note: P1= C3N2 (blue color, 15 lux); P2= C3N3 (blue color, 20 lux); P3= C4N2 (green color, 15 lux). Means in the same row with different superscripts differ significantly $(\mathrm{p}<0.05)$. 
light color with an intensity of $15 \mathrm{lux}$ ) as the best treatment, with the respective values of HU 95.11 \pm 2.39 , EYI $0.421 \pm 0.63$, EGA $0.133 \pm 0.12$, and yolk color $8.36 \pm 0.31$.

Table 4 shows the external quality variables, and ANOVA confirms the significant effect of different LED monochromatic light colors and intensity on all variables $(p<0.05)$. These include average egg weight, where P1 treatment (a combination of blue light color with an intensity of 15 lux) was the highest at $66.7635 \pm 5.21 \mathrm{~g} /$ egg, and total egg weight of $1,373.12 \pm 16.5 \mathrm{~g} / \mathrm{duck} / 4$ weeks. This value was higher than the average egg weight of duck under P2 (blue light color with an intensity of $20 \mathrm{lux}$ ) and P3 (green light color with an intensity of 15 lux) at $66.4603 \pm 6.45$ and $62.4754 \pm 6.86$ g/grain, respectively.

\section{DISCUSSION}

\section{Productivity of Alabio Duck Eggs}

Egg productivity is presented in Table 1, the interaction of color with light intensity results obtained shows a significant difference $(\mathrm{p}<0.05)$ on egg productivity. The results of this study are congruent with Rozenboim et al. (2004) and Kim et al. (2012), where the differences in LED light color and intensity cause variations in egg productivity. This is due to differences in the wavelength of each monochromatic color emitted.

Table 1 shows higher production with exposure to blue and green, compared to red and yellow. Meanwhile, the intensities of 15 and 20 lux produced a more positive impact than 10 lux. These findings agree with Jin et al. (2011), who found that 15-20 lux was recognized as the intensity with the capacity to stimulate duck ovulation. Yahav et al. (2000) attributed the preference for low light intensity (10 lux) in broiler poultry (turkey) than laying poultry, to speed the increase in body weight, achieved through improved feed conversion. According to Shabiha et al. (2013), blue and green light have shorter wavelengths of around $480 \mathrm{~nm}$ and $520 \mathrm{~nm}$ compared to yellow (580 nm) and red (700 $\mathrm{nm})$, hence the higher stimulation effectivity on the eye retina, hypothalamus, and pituitary gland. This cascade of events leads to the production of reproductive hormones with the capacity to stimulate egg ovulation processes, including the follicle-stimulating hormone (FSH), luteinizing hormone (LH), estrogen, and progesterone. Also, Kasiyati (2018) reported on the ability of blue and green light to increase the synthesis and secretion of estradiol in local poultry. This consequently elevates the number of functional ovarian follicles and guarantees sustainability in egg production. Hasan et al. (2013) and Biyatmoko (2014) reported on the support provided by reproductive hormones towards quicker ovarian development and maturation, elevation in oviduct development, and also initiates the egg production stages. Conversely, irradiation with yellow light is not effective in laying poultry, due to the relatively lower production level and efficiency of feed use (Borille et al., 2013). Furthermore, red and yellow lights enhanced poultry aggressiveness and active movement, leading to higher consumption of feed energy for locomotion, and the subsequent decline in egg production. Meanwhile, blue light has the ability to reduce locomotion (movement activity) and standing, hence the increase in calmness (Hassan et al., 2014; Huber et al., 2013). In addition, poor locomotion elevates energy and protein supply efficiency. This is fully manifested during egg production (Kim et al., 2012), and higher yield is obtained on exposure to blue and green LED monochromatic lights (Freitas et al., 2010).

Light regulates daily rhythm, and important bodily functions, including temperature and metabolic processes related to feeding and digestion, subsequently affecting poultry egg production (Olanrewaju et al., 2012). Therefore, the addition of artificial light at night, and extending the exposure time through the ahemeral method (18L: 10D), stimulates the pituitary gland, This further increases the secretion of FSH hormone, and bluffs the ovary activation, in order to achieve the oviposition process or egg-laying (Hassan et al., 2013). Conversely, Firouzi et al. (2014) emphasized the ability for red and yellow lights to increase chicken activity, by triggering aggressiveness and movement. This causes the fulfillment of feed intake, hence the high recommendation for use in the starter maintenance phase (brooding), and not in the laying phase or for broilers (Morrill et al., 2014). Olanrewaju et al. (2012) attributed the ducks' efficient use of feed consumption for egg production, to the proper management of energy during locomotion or other activities. Cao et al. (2008) reported on the higher effectiveness of green light in stimulating testosterone secretion and myofibril growth, subsequently resulting in increased body weight.

\section{Performance of Alabio Duck Production}

The color and light intensity interaction has a significant effect $(p<0.05)$ on the age at first laying eggs, where C3N2 treatment, namely the interaction of blue light color with light intensity 15 lux, produces an earlier age ranging from $164 \pm 1.9$ days, $C 2 N 1$ treatment is a red light color with an intensity of 10 lux of $167 \pm 3.3$ days and C3N3, namely the color of blue light with an intensity of 20 lux ranging from 168 \pm 2.4 days. These findings were corroborated by Parvin et al. (2014) where the provision of artificial light using monochromatic LED light at night was estimated to stimulate reproductive system development, therefore the bird quickly reaches sexual maturity. Furthermore, molting is also experienced earlier, compared to those placed under dark night conditions without additional light (Yang et al., 2016). The first ovulation process is an indicator of puberty in females (Etches, 2000). Min et al. (2012) reported on the earlier onset in laying pullet cultivation after extending the light from 6 to 18 hours (18L: 6D). According to Shabiha (2013), blue-colored irradiation with a short wavelength of $480 \mathrm{~nm}$ is more effective in stimulating the retina, compared to green, yellow, and red at 520-700 nm. This is also able to stimulate the hypothalamus, and proceeded by the pituitary gland to produce Gonadotropins, in the form of follicle-stimulating hormone (FSH) and luteinizing hormone (LH), estrogen, and progesterone. Furthermore, all four hormones play a very instrumen- 
tal role in accelerating puberty (reproduction process), hence the first egg is produced relatively earlier with blue LED monochromatic light (Hassan et al., 2013). Moreover, exposure to light affects the vision process of laying poultry and subsequently stimulates the release of growth and reproductive hormones, and also the internal reproductive cycle. These activities lead to the commencement of the egg production process (Mohamed et al., 2014). According to Lewis \& Morris (2006), continuous lighting, as seen with the ahemeral method, normally stimulates FSH release. In addition, follicular development initiates the release of estrogen in external theca cells, at the prehierarchical follicles, while granulosa cells secrete progesterone. Therefore, prehierarchical follicles develop into hierarchical types, leading to an increase in the amount of estrogen secreted. This hormone helps to increase the calcium, protein, fat, and vitamin composition alongside other substances in the blood needed in egg formation. Subsequently, further development in the size of hierarchical follicles, especially the F1 position, paradoxically suppresses estrogen secretion and increases progesterone synthesis by preovulation follicles. This consecutively stimulates the anterior pituitary to secrete $\mathrm{LH}$, and the transmission into the blood is positive feedback, therefore initiating ovulation. The process involves the release of matured yolk from stigma in the ovary into the infundibulum. Liu et al. (2015) reported on the positive impact of blue and green light in the final stages of egg production, marked by the increased secretion of estradiol and progesterone, and also in hormone-receptors expressions, and accelerated puberty. These activities facilitate the onset of egg production, as an indication of sexual maturity.

The differences in color and intensity of the LED monochromatic light produced a significant effect on all treatments $(\mathrm{p}<0.05)$, in the aspect of total egg weight, feed consumption and conversion (FCR). Furthermore, the best achievement was observed in C3N2 (blue light color and intensity of 15 lux), with a total egg weight of $1,373.12 \pm 16.5 \mathrm{~g} / \mathrm{head}$, feed consumption of $810.12 \pm 13.5 \mathrm{~g} /$ head, and FCR of $4.13 \pm 1.3$. These three variables performance factors of laying poultry serve asfeasibility determinants for the business. Specifically, FCR shows the efficiency of feed used to produce egg output (Biyatmoko, 2016), and C1N1 treatment (yellow light color with an intensity of $10 \mathrm{lux}$ ) had the lowest value at 6.44. However, the increased egg weight in C3N2 treatment caused an upsurge in serum estradiol secretion, followed by elevated ovarian weight and F1 follicle diameter. These increments lead to the larger and heavier yolk (vittelin), and subsequently impact the overall egg weight (Freitas et al., 2010; Kasiyati et al., 2016). In addition, blue irradiation improves calmness, and feed use efficiency (FCR) in poultry (Rozenboim et al., 2004), and is fully convertible to continuous egg production (Hassan et al., 2013). This is due to the more efficient feed consumption as ducks spend less energy on locomotion needs (Olanrewaju et al., 2012). However, excessive light intensity tends to disrupt the daily diurnal rhythm of egg production. Li et al. (2014) reported on the need to balance the blue and green lights provided with an adequate amount of lumens per watt, for optimal yield. In addition, improvement in ration consumption is more influenced by the color, because the wavelength plays a major role in determining livestock behavioral changes (Kim et al., 2012). The poultry has different visual sensitivity, and the color received by the retina is distinguished at distinct levels, according to wavelength (Firouzi, et al., 2014).

The duck mortality in this study was considered to be low, at $0.00 \%$ to $6.67 \%$, equivalent to $0-1$ head per treatment. However, the death did not result from the effects of treatment but was rather due to non-technical issues. This includes demise because the head is trapped between the cage grille, or the legs get stuck in the cage at night. Based on these observations, the mortality variable was not ascertained as a proper measure of monochromatic light treatment effectiveness, using the ahemeral method. The more suitable determinant include variables of egg production, duck performance, and income (IOFC).

The IOFC generated refers to the income obtained per duck from each treatment, and C3N2, at IDR $29,405.39 \pm 333.1 /$ head/month, was recognized as the best. This yield is higher than the result of Erlina research (2013) on intensive Alabio laying ducks farming in Babirik village, HSU Regency, with an IOFC of IDR $4,918.33 /$ head/month equivalent to IDR $7,377,500 / 300$ heads/5 months. Also, the report of Budiraharjo (2009) on Tegal species was IDR 7,551.45/head/month without additional lighting, while Suryana (2007) calculated IDR 10,554.02/head/month, equivalent to IDR 126.64 million/1000 heads/year, for the MA (Mojosari-Alabio) species.

Three best treatments were recommended based on the measurements and observations in the first stage, in terms of productivity (total, average, and production level), performance (first egg-laying age, total egg weight, feed consumption, FCR, duck mortality), and income (IOFC) (egg sales results, feed costs, income). These were then applied in the second stage of research, including 1) C3N2 (blue light color, the intensity of 15 lux), 2) C3N3 (blue light color, the intensity of 20 lux), and 3) C4N3 (green light color, the intensity of 20 lux).

\section{Internal and External Quality of Eggs}

Table 4 shows a significant interaction $(p<0.05)$, between color and light intensity on the internal quality of duck eggs, both against haugh units (HU), egg yolk index (EYI), egg albumin index (EAI) and yolk color $(p<0.05)$. The interaction between blue light color and intensity of 15 lux (P1) showed the best internal egg quality results, namely the Haugh unit (HU) of 95.11 \pm 2.39 , the yolk index (IKT) of $0.421 \pm 0.63$, the egg white index (IPT) was $0.133 \pm 0.12$ and the egg yolk color value was $8.36 \pm 0.31$. Borille et al. (2015) reported on the capacity for the shortest wavelength $(450 \mathrm{~nm})$ observed in blue light to directly penetrate and be absorbed by the skull bones and cranial tissue. They are also received by extraretinal photoreceptors to reach the hypothalamus, and the signal is subsequently forwarded to the pituitary to secrete a variety of hormones (FSH and $\mathrm{LH}$ ), which play a role in the reproductive process. These further 
stimulate the development and maturation of ovarian follicles, from the preovulation stage, where an increase in estrogen secretion causes the enlargement observed 3-6 hours before ovulation (Zhu et al., 2019). Biyatmoko (20014) affiliated exposure to greater irradiation lengths with higher feed intake, including protein consumption, known to increase vittelin or egg yolk deposits in the follicles upon ovulation.

Table 4 shows the linear decline in HU from P1, P2 to $\mathrm{P} 3$, similar to the EAI values, at $0.133 \pm 0.12,0.121 \pm 0.16$, and $0.103 \pm 0.19$. Er et al. (2014) reported the use of monochromatic light to increase yolk index (EYI) and Haugh unit (HU). Moreover, Haugh unit is a measure of protein quality, evaluated based on the albumen height and egg weight (Monira et al. 2003). The increase in value is linear with the egg white index (EAI), measured by dividing the height of thick albumen by half of the total longest and shortest diameters (Suswoyo \& Rosidi, 2016). The color of egg yolk was a key factor for quality, based on several consumer surveys (Jacob et al., 2000), but this preference is very subjective, with variations from different countries. However, the Roche yolk color fan was used to establish a standard, and the results on evaluation were compared to obtain a color score. The findings indicate a more orange egg yolk in P1 (exposure of blue light color with an intensity of 15 lux), with a score of $8.36 \pm 0.31$, followed by P2 (blue light color, the intensity of $20 \mathrm{lux}$ ) at 7.86 \pm 0.26 , and P3 (green light color, the intensity of 15 lux) at $7.12 \pm 0.33$.

Table 4 shows a significant interaction $(p<0.05)$ between color and light intensity on the external quality of egg weight, shell thickness, egg shape index (IBT), and specific gravity. The highest egg weight produced by $\mathrm{P} 1$ treatment is a combination of blue light color with an intensity of 15 lux of $66.7635 \mathrm{~g} / \mathrm{egg}$, higher compared to treatment P2 (blue light color, 20 lux intensity) and P3 (green light color, 15 lux intensity) respectively at $66.4603 \mathrm{~g} / \mathrm{egg}$ and $62.4754 \mathrm{~g} / \mathrm{egg}$. Kasiyati et al. (2016) attributed the increased egg weight in P1 to the significant effect of blue light and 15 lux intensity on elevated serum estradiol secretion and also the increase in ovarian weight and F1 follicle diameter. This growth is directly proportional to the larger and heavier yolk weight (vittelin) (Freitas et al., 2010), and consequently has an impact on the egg weight (Kasiyati et al., 2016). This finding was congruent with a report by Rozenboim et al. (2004), where the blue irradiation was able to improve feed efficiency and ensure the full conversion into continuously produced heavier eggs (Hassan et al., 2013).

\section{CONCLUSION}

The combination of blue light color with an intensity of 15 lux significantly increased the egg production and performance of Alabio duck. This includes the variables of total productivity, HDP production level, mortality, first egg-laying age, total egg weight, feed consumption, feed conversion ratio (FCR), and also generated the highest income (IOFC). Furthermore, the blue light color with an intensity of 15 lux produced the best properties on an average, including both the internal qualities of haugh unit (HU), egg yolk index (EYI), egg albumin index (EAI), and yolk color, as well as the external attributes of total egg weight, shell thickness, shape index (ESI), and specific gravity (sg).

\section{CONFLICT OF INTEREST}

The authors also declare that there is no conflict of interest with any financial, and personal, issues or organization in relation to the material used in this paper

\section{ACKNOWLEDGEMENT}

The authors are grateful to the Director of Research and Community Service (DRPM), Ministry of Research, Technology and Higher Education for the Higher Education Applied Research (PTUPT) funding in 2019 and 2020

\section{REFERENCES}

Biyatmoko, D. 2014. Effect of utilization of several calcium sources in feed on external and internal egg quality of Alabio laying duck. Asian Academic Research Journal of Multidisciplinary 1: 47-56.

Biyatmoko, D. 2016. The effect of protease enzyme supplementation to productivity eggs of alabio duck. Inter. J. Biosciences 8: 202-208. https://doi.org/10.12692/ ijb/8.2.202-208

Borille, R., R.G. Garcia, A.F.B. Royer, M.R. Santana, S. Colet, I.A. Naas, F.R. Caldara, I.C.L. Almeida, E.S. Rosa, \& V.A.R. Castilho. 2013. The use of light-emitting diodes (LED) in commercial layer production. J. Rev. Bras. de Ciência Avícola. 15: 135-140. https://doi.org/10.1590/ S1516-635X2013000200009

Borille, R., R.G. Garcia, I.A. Naas, F.R. Caldara, \& M.R. Santana. 2015. Monochromatic light-emitting diode (LED) source in layers hens during the second production cycle. J. Rev. Bras. Eng. Agr. Amb. 19: 877-881. https://doi. org/10.1590/1807-1929/agriambi.v19n9p877-881

Budiraharjo, K. 2009. Analisis Profitabilitas Pengembangan Usaha Ternak Itik di Kecamatan Pagerbarang Kabupaten Tegal. J. Mediagro 5: 15-22.

Cao, J., Z. Liu, D. Wang, D. Xie, L. Jia, \& Y. Chen. 2008. Green and blue monochromatic light promote growth and development of broilers via stimulating testosterone secretion and myofiber growth. J. Appl. Poult. Res. 17: 211-218. https://doi.org/10.3382/japr.2007-00043

Cao, J., Z. Wang, Y. Dong, Z. Zhang, J. Li, F. Li, \& Y. Chen. 2012. Effect of combinations of monochromatic lights on growth and productive performance of broilers. J. Poult. Sci. 91: 3013-3018. https://doi.org/10.3382/ps.2012-02413

Chen, W.L. \& T. F. Shen. 1989. Comparative studies on the utilization of calcium between laying Tsaiya duck and Leghorn hen. Asian J. Anim Sci. 2:67-72. https://doi. org/10.5713/ajas.1989.67

Chew, T.T., T. Phathanawiboon, \& A.M. Easa. 2016. Quality, textural, and sensory properties of yellow alkaline noodles formulated with salted duck egg white. J. Food Qualty 39: 342-350. https://doi.org/10.1111/jfq.12203

Etches, R. J. 2000. Reproduction in Poultry. CAB International, Singapore.

Elert, G. 2008. The nature of light. http://hypertexbook.com/ physics/. (4 Mei 2020).

Firouzi, S., H. Nazarpak, H. Habibi, S.S. Jalali, Y. Nabizadeh, F. Rezaee, R. Ardali, \& M. Marzban. 2014. Effects of color lights on performance, immune response and hematological indices of broilers. J. World's Poult. Res. 4:52-55. 
Er, D., Z. Wang, J. Cao, \& Y. Chen. 2007. Effect of monochromatic light on the egg quality of laying hens J. Appl. Poult. Res. 16: 605-612. https://doi.org/10.3382/japr.2006-00096

Erlina, S. 2013. The relationship between agribusiness subsystems of the Alabio layer ducks in Hulu Sungai Utara District South Kalimantan Province. IJAS. 3:73-77. https:// doi.org/10.24198/ijas.v3i3.15051

Freitas, H.J., J.T.B. Cotta, A.L. Oliveira, L. D.S. Murgas, \& C.E. Gewehr. 2010. Effects of different lighting programs in laying hens housed in free range. J. Revista Biotemas. 23: 157-162. (in Portuguese)

Gordon, S.H. 1994. Effects of day length and increasing daylength programmes on broiler welfare and performance. Word Poultry Science Journal 50:269-282

Hafez, E. S. E. 2000. Reproduction in Farm Animals. 7th Ed. Lea \& Febiger. Philadelphia. Pp. 385-398. https://doi. org/10.1002/9781119265306

Hassan, M.R., S. Sultana, H. S. Choe, \& K. S. Ryu. 2014. Effect of combinations of monochromatic led light color on the performance and behavior of laying hens. J. Poult. Sci. 51:321-326. https://doi.org/10.2141/jpsa.0130105

Hassan, R.M.D., S. Sultana, H. H. Sung, \& R. K. Saon. 2013. Effect of monochromatic and combined light colour on performance, blood parameters, ovarian morphology and reproductive hormones in laying hens. Ital. J. Anim. Sci. 12: 1-6. https://doi.org/10.4081/ijas.2013.e56

Huber-Eicher, B., A. Suter, \& P. Spring-Stahli. 2013. Effects of colored light-emitting diode illumination on behavior and performance of laying hens. Poultry Sci. 92: 869873. https://doi.org/10.3382/ps.2012-02679

Jacob, J.P., R.D. Miles, \& F.B. Mather. 2000. Egg Quality. University of Florida. http://edis.ifas.ufl.edu/pdffiles/PS/ PS02000.PDF.

Jin, E., I. Jia, J. Li, G. Yang, Z.Wang, J. Cao, \& Y. Chen. 2011. Effect of monochromatic light on melatonin secretion and arylalkylamine N-Acetyltransferase mRNA expression in the retina and pineal gland of broilers. The Anatomical Record 294:1233-1241. https://doi.org/10.1002/ar.21408

Kasiyati. 2018. The role of light in birds life: the response of growth and reproduction. J. Buletin Anatomi dan Fisiologi 3: 116-125. https://doi.org/10.14710/baf.3.1.2018.116-125

Kasiyati, D. Sumiati, R. Ekastuti, \& W. Manalu. 2016. Roles of curcumin and monochromatic light in optimizing liver function to support egg yolk biosynthesis in Magelang ducks. Inter. J. Poult. Sci. 15:414-424. https://doi. org/10.3923/ijps.2016.414.424

Kim, M.J., M. S. Hossian, A. Nazma, C. N. Jae, T.B. Han, K. K. Hwan, W. K. Dong, H. C. Chae, H. C. Choi, \& S. S. Oks. 2012. Effect of monochromatic light on sexual maturity, production performance and egg quality of laying hens. J. Avian Biol. Res. 5:69-74.

Kim, M.J., M.M. H. Parvin, J.H. Musthaq, D.W. Kim, H. K. Kim, J. C. Kang, C. D. Hwangho, K. O. Kim, C. B. Cho, \& H.C. Yang. 2014. Influence of colored light-emitting diode illumination on the growth performance and meat quality trait of Pekin duck (Anas platyrhynchos). Bul. J. Agri. Sci. 20:943-948. https://doi.org/10.3184/17581551 2X13350270679453

Lewis, P. \& T. Morris. 2006. Poultry Lighting The Theory and Practice. Northcot. United Kingdom.

Liu, L., D. Li, E.R. Gilbert, Q. Xiao, X. Zhao, Y. Wang, H. Yin, \& Q. Zhu. 2015. Effect of monochromatic light on expression of estrogen receptor (ER) and progesterone receptor (PR) in ovarian follicles of chicken. Plos One 10: 1-14. https:// doi.org/10.1371/journal.pone.0144102

Li, D., L. Zhang, M. Yang, H. Yin, H. Xu, J. S. Trask, D. G. Smith, Z. Zhang, \& Q. Zhu. 2014. The effect of monochromatic light-emitting diode light on reproductive traits of laying hens. J. Appl. Poult. Res. 23:367-375. https://doi. org/10.3382/japr.2013-00746

Mattjik, A.A. \& I.M. Sumertajaya. 2006. Perancangan Percobaan dengan Aplikasi SAS dan Minitab. IPB Press, Bogor.

Min, J.K., M.S. Hossan, A. Nazma, C.N. Jae, T.B. Han, \& K.K. Hwan. 2012. Effect of monochromatic light on sexual maturity, production performance and egg quality of laying hens. J. Avian Biol. Res. 5: 69-74. https://doi.org/10.3184/17 $5815512 X 13350270679453$

Mohamed, R.A., M.M. Elthoth, \& N. R. El-Saidy. 2014. Rearing broiler chickens under monochromatic blue light improve performance and reduce fear and stress during preslaughter handling and transportation. J. Bio. Anim. Husb. 30: 457-471. https://doi.org/10.2298/BAH1403457M

Monira, K., N. Salahuddin \& M. Miah. 2003. Effect of breed and holding period on egg quality characteristic of chicken. Inter. J. Poult. Sci. 2:261-263. https://doi.org/10.3923/ ijps.2003.261.263

Morrill, W.B.B., J.M.C. Barnabé, T.P.N. Da Silva, H. Pandorfi, A.S. Gouveia-Neto, \& S.S. Wellington. 2014. The effect of RGB monochromatic and polychromatic LED lighting on growth performance, behavior, and development of broilers. Proceedings of Society of Photo-Optical Instrumentation Engineers, San Francisco, CA, USA. https://doi.org/10.1117/12.2036602

North, M. O. \& D. D. Bell. 1992. Commercial Chicken Production Manual. 4th Edition. An AVI Book Published by Van Nostrand Reinhold. New York.

Olanrewaju, H.A., P.L. Purswell, S.D. Collier, \& S.L. Branton. 2012. Influence of photoperiod, light intensity, and their interaction on growth performance and carcass characteristics of broilers grown to heavy weights. Int. J. Poult. Sci. 11:739-746. https://doi.org/10.3923/ijps.2012.739.746

Parvin, R., M.M.H. Mushtaq, M.J. Kim, \& H.C. Choi. 2014. Light emitting diode (LED) as a source of monochromatic light: a novel lighting approach for behaviour, physiology and welfare of poultry. J. World Poult. Sci. 70: 543-556. https://doi.org/10.1017/S0043933914000592

Rozenboi, I., Y. Bira, S. Chaiseha, A. Yahav, D. Rosenstrauch, O. Sklan, \& Halevy. 2004. The effect of a green and blue monochromatic light combination on broiler growth and development. J. Poult. Sci. 83: 842-845. https://doi. org $/ 10.1093 / \mathrm{ps} / 83.5 .842$

Shabiha, S., R. Hasan, H. S. Choe, \& K.S. Ryu. 2013. Impact of different monochromatic LED light colour and bird age on the behavioral output and fear response in ducks. Ital. J. Anim Sci. 12: 573-584.

Suryana. 2007. Prospek dan peluang pengembangan itik Alabio di Kalimantan Selatan. J. Litbang Pertanian 26: 109-114.

Suswoyo, I. \& Rosidi. 2016. Welfare and egg production of local ducks fed diets containing two probiotics in commercial farms. Int. J. Poult. Sci. 15: 235-239. https://doi. org/10.3923/ijps.2016.235.239

Svobodová, J., E. Tůmová, E. Popelářová, \& D. Chodová. 2015. Effect of light colour on egg production. Czech J. Anim. Sci. 60: 550-556. https://doi.org/10.17221/8597-CJAS

Yahav, S., S. Hurwitz, \& I. Rozenboim. 2000. The effect of light intensity on growth and development of turkey toms. J. Poult. Sci. 41: 101-106. https://doi.org/10.1080/00071660086484

Yang, Y.F., J.S. Jiang, J.M. Pan, Y.B. Ying, X.S. Wang, M.L. Zhang, M.S. Lu, \& X.H. Chen. 2016. The relationship of spectral sensitivity with growth and reproductive response in avian breeders (Gallus gallus). J. Sci. Rep. 6: 1-9. https://doi.org/10.1038/srep19291

Zhu, H.X., M.D. Hu, B.B. Guo, X. L. Qu, M.M. Lei, R. Chen, Z. Chen, \& Z.D. Shi. 2019. Effect and molecular regulatory mechanism of monochromatic light colors on the egg-laying performance of Yangzhou geese. J. Anim. Reprod. Sci. 204:131-139. https://doi.org/10.1016/j. anireprosci.2019.03.015 